ISSN: 2224-0616

Int. J. Agril. Res. Innov. \& Tech. 6 (2): 12-23, December, 2016 Available online at http://www.ijarit.webs.com

\title{
DIVERSITY AND DYNAMICS OF RHIZOBIAL POPULATIONS IN ACIDIC SOILS WITH ALUMINUM AND MANGANESE TOXICITIES IN FOREST ZONES
}

\author{
Linda Manet²,3, Onana Boyomo1, Eddy Léonard Mangaptche Ngonkeu2,3, Aimé Didier \\ Boyogueno Begoudé ${ }^{3}$ and Papa Saliou Sarr ${ }^{*}$
}

Received 17 August 2016, Revised 28 November 2016, Accepted 27 December 2016, Published online 31 December 2016

\begin{abstract}
Soil acidity in the humid forest zones of Cameroon is one of the major constraints to agricultural productivity. This study was carried out to assess the rhizobial communities of two acidic soils; with aluminum toxicity (Nkoemvone) and manganese toxicity (Nkolbisson) for their potential to improve soil fertility in Cameroon. These two soils were used to inoculate to the host plants cowpea and siratro. At harvest, 120 rhizobacterial isolates were extracted from the nodules of these two hosts and subjected to morphological characterization. Twenty isolates per site were selected and analyzed for their 16S rDNA genetic profile following restrictions with endonucleases of PCR products and electrophoresis. The restriction patterns of the 16S rDNA of the 40 isolates showed 12 different profiles. Eight occurred in both types of soils, where as 4 were specific to the manganese-toxic-acidic soil. While the $\mathrm{Al}$ toxicity reduced the nodulation and growth of both plants, the Mn toxicity mostly affect the cowpea. This study ascertained the distribution of rhizobia based on soil characteristics. Further molecular analyses would allow the identification of the isolates recovered as well as their phylogenetical relationships.
\end{abstract}

Keywords: Acidity, Al and Mn Toxicity, Rhizobia, Diversity, PCR-RFLP

${ }^{1}$ Department of Microbiology, Faculty of Science, University of Yaounde I. P.O. Box: 812 Yaounde, Cameroon

${ }^{2}$ Department of Plant Biology, Faculty of Science, University of Yaounde I. P.O. Box: 812 Yaounde, Cameroon

${ }^{3}$ Biological Control and Applied Microbiology Laboratory, IRAD, P.O.Box:2067, Cameroon

${ }^{4}$ Laboratory of Plant Gene Expression, Research Institute for Sustainable Humanosphere, Kyoto University, Gokasho, Uji 611-0011, Japan

*Corresponding author's email: pesseus77@yahoo.fr (Papa Saliou Sarr)

\section{Introduction}

Carbon dioxide assimilation by photosynthetic organisms and biological nitrogen fixation by diazotrophic bacteria, represent both the two main biological processes at the base of the development of the living world (Domergue, 2006). Biological fixation of nitrogen, which represents $65 \%$ of the total amount produced annually is ensured by diazotrophic bacteria (Newton, 1998). These bacteria possess anitrogenase enzyme complex responsible for the reduction of molecular nitrogen (Rees and Howard, 2000). This enzyme has been demonstrated to occur only in prokaryotes (Postgate, 1974). Presently, two classes of nitrogen-fixing can be distinguished: the free fixers that are not associated with any living organisms whereas symbiotic fixers are commonly associated with specific plants (Dommergues and Krupa, 1978). Up to now, it is estimated that a wide range of rhizobacterial organisms, comprising at least 14 genera distributed over 50 species have been described. Currently, the Alphaproteobacteria such as
Bradyrhizobium, Azorhizobium, Ensifer (Sinorhizobium), and Mesorhizobium (members of these genera are collectively termed "rhizobia") and two genera of Betaproteobacteria have been documented for diverse legumes. The early studies of Beta-rhizobia suggested that they might have a close affinity with the large legume genus Mimosa (Mimosoideae), which contains $>500$ species, with Brazil as their main center of radiation. This affinity has been demonstrated for Mimosa spp. in the Cerrado and Caatinga, which were almost exclusively nodulated by Burkholderia (Gyaneshwar et al., 2011; Gehlot et al., 2013).

Fourteen years after the first description of Betarhizobia, they are now being shown to be highly diverse, and to comprise several groups (especially in the genus Burkholderia) that have affinities with tropical and subtropical legumes. The root nodulating ability of Betaproteobacteria may also be extended into new genera, such as Herbaspirillum and Achromobacter, but more conclusive data on their nodulation abilities are 
required to establish their status as true symbionts (Elliott et al., 2009; Lemaire et al., 2015). Thus, soil rhizobia supply substantial amounts of nitrogen to agro-ecosystems. Together with mycorrhizae, which improve phosphorus, water and other minerals uptake, they form an ecologically important microbial group that maintain or improve soil fertility (Duponnois et al., 2012). Due to its considerable agricultural and environmental significance, the legume-symbionts are being extensively used as an alternative of synthetic fertilizers to supply nitrogen requirements of plants in agroecosystems. Plants require three factors for their growth and reproduction: light, water, and nutrients. In Cameroon, low-fertility soils are a major constraint to crop production. In the forest zone of Cameroon, the biophysical context is also one most likely major factor explaining the poor fertility of agricultural soils. There are in Cameroon a wide variety of soils linked to parent rocks, topographic factors and bioclimatic environments. Six major categories of soils are represented in Cameroon: unskilled or low evolved soils, vertisols, andosols and brown soils, fersiallitic and ferruginous soils, ferralitic soils and waterlogged soils (National Institute of Cartography, 2010). The specific case in our study concerns the ferralitic soils, which cover $2 / 3$ of the country from south to the eighth parallel. These are nutrient- poor soils, acid and fragile. They are largely covered by forest, well developed, very permeable and rich in humus. In the tropics, agricultural production faces numerous constraints including soil acidity permanently associated with both low availability of soil nutrients such as nitrogen, phosphorus, potassium as well as substantial increase in aluminum and manganese toxicity (Brady and Weil, 2002). In the particular case of Cameroon, acid soils cover 75 to $80 \%$ of the completely arable land (Bindzi-Tsala, 1987), hence leading to important constraints in agricultural production activities. Management options used for countering the harmful effects of acidity depend on the type of stress to which is submitted the land use system. Now, different soil management strategies for enhanced crop production include liming, use of tolerant plants, fertilizer application, and the use of leguminous plants for their potentiality to biologically fix atmospheric nitrogen. Nitrogen $(\mathrm{N})$ is the most significant yield-limiting element in many agricultural production systems. External inputs of $\mathrm{N}$ to agriculture may come from inorganic fertilizers, the production of which is heavily dependent on fossil fuels. Rhizobium-legume symbiosis represents more than 30 to $300 \mathrm{~kg} \mathrm{~N}^{-1}$ (Elmerich, 1993), which provides nearly half of all requirements used in agriculture. Biological processes control nutrient cycling and influence many other aspects of soil fertility. This process affects soil biology, especially microbial activity, root growth, and organic matter, and are key factors in efficient nutrient management. Specific strains of rhizobia are required to make functional root nodules to be able to fix the $\mathrm{N}_{2}$. The presence of these rhizobia is very beneficial for the legume, as it potentially increases the yield of the crop due to the increase of $\mathrm{N}_{2}$ fixation. Field inoculations with adapted efficient strains would assist farmers in their efforts to enhance agricultural production.

The main objective of this study was to assess rhizobial communities of 2 acidic soils; one with aluminum toxicity and the other with manganese toxicity. For this purpose, 120 isolates were extracted from fallows at Nkoemvone and Nkolbisson and characterized morphologically. From each site, 20 isolates of rhizobacteria were selected for analysis of their 16S rDNA genetic profile following restrictions with endonucleases and electrophoresis.

\section{Materials and Methods}

\section{Study area}

Experiments were conducted in the agroecological area $\mathrm{V}$ in humid forest zone of Cameroon, corresponding to the Central, Southern and Eastern regions. The central and southern regions were selected in this study based on contrasting acidity opposing Nkolbissonto Nkoemvone. The Nkolbisson site $\left(11^{\circ} 36^{\prime} \mathrm{E} ; 3^{\circ} 44^{\prime} \mathrm{N}\right)$ in the central region (Yaounde) is distant of $180 \mathrm{~km}$ from the Nkoemvone site $\left(2^{\circ} 40^{\prime} \mathrm{N} ; 12^{\circ} 24^{\prime} \mathrm{E}\right)$ located in the southern region (Ebolowa). At Nkolbisson, the average annual temperature is $23.5^{\circ} \mathrm{C}$, the rainfall is bimodal, the annual rainfall average is $\mathbf{1 5 6 0}$ $\mathrm{mm}$, and the soil is clayey loam texture with a strong tendency to water logging and manganese toxicity. The Nkoemvone site in the heart of the humid forest zone is at $615 \mathrm{~m}$ above sea level. Its climate is Guinean bimodal rainfall with an average rainfall of $1875 \mathrm{~m}$ and an average temperature of $24^{\circ} \mathrm{C}$ (Kamdje et al., 1986). The soil is clayey and toxic in aluminum. Soil samples were taken from fallows of 5 years old in these two sites. Botanical species in the fallow systems included several taxa such as Centrosemas pubescens, Pennisetum purpureum, Bracharia, Mucunasp and Sesbania sp. for the Nkoemvone (Ebolowa) site, and Centrosema pubescens, Musa invisa for Nkolbisson (Yaounde) site. Soil samples collected were used to inoculate seeds of cowpea (Vigna unguiculata) and siratro (Macroptilium atropurpureum) selected as trap plants for the isolation of rhizobia from nodules, and for soil physico-chemical analysis. From each fallow, soil samples collected from ten (10) 
sampling points were mixed to constitute a composite sample per site. The samples were collected between 0 and $20 \mathrm{~cm}$ depth for assessment of rhizobial diversity in central (Yaounde) and southern (Ebolowa) regions in the humid forest zone of Cameroon.

\section{Soil analy sis}

Samples were passed through a $0.5 \mathrm{~cm}$ mesh to remove any plant or grass fragment at the field. At laboratory (IITA, Yaounde-Cameroon), they were air-dried and ground to pass through a 2 $\mathrm{mm}$ sieve. Soil $\mathrm{pH}$ was determined in a 1:2.5 (w/v) soil: water suspension. Organic carbon was determined by chromic acid digestion (Black, 1982) and spectrophotometric analysis (Heanes, 1984). Soil N (\%) was determined by wet acid digest (Buondonno et al., 1995) and analyzed colorimetrically (Anderson and Ingram, 1993). Exchangeable $\mathrm{Ca}, \mathrm{Mg}, \mathrm{K}$, and $\mathrm{Na}(\mathrm{mmol} / \mathrm{kg})$ were extracted using $1 \mathrm{M}$ ammonium acetate and determined by atomic absorption spectrophotometry. Soil available phosphorus ( $\mathrm{mmol} / \mathrm{kg}$ ) was extracted by the Bray-1 procedure (Bray and Kurtz, 1945) and analyzed using the molybdate blue procedure described by Murphy and Riley (1962). Exchangeable Zn, Cu, Mn and Fe were extracted using Mehlich 3 procedure (Mehlich, 1984) and determined by atomic absorption spectrophotometer. CEC was determined by ammonium acetate extraction and quantified colorimetrically. Exchangeable Al was extracted using $1 \mathrm{~N} \mathrm{KCl}$ (Barnhisel and Bertsch, 1982) and analyzed by the pyrocatechol violet method as described by Mosquera and Mombiela

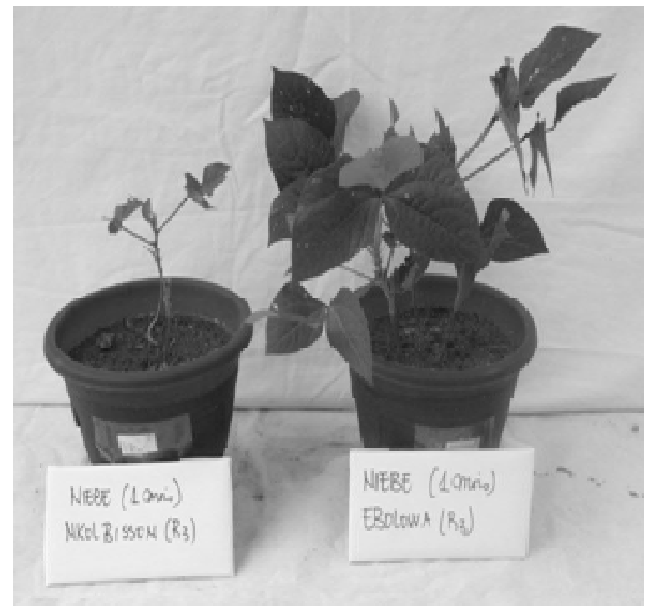

Fig. 1. Cowpea (niebe) and Siratro plants after one month growth.

Isolation and characterization of isolates

A total of 120 nodules were harvested from plants roots. Following the traditional methods described by Vincent (1970) and Somasegaran and Hoben (1985), the nodules were washed with ethanol (95\%) for 30 seconds, disinfected with

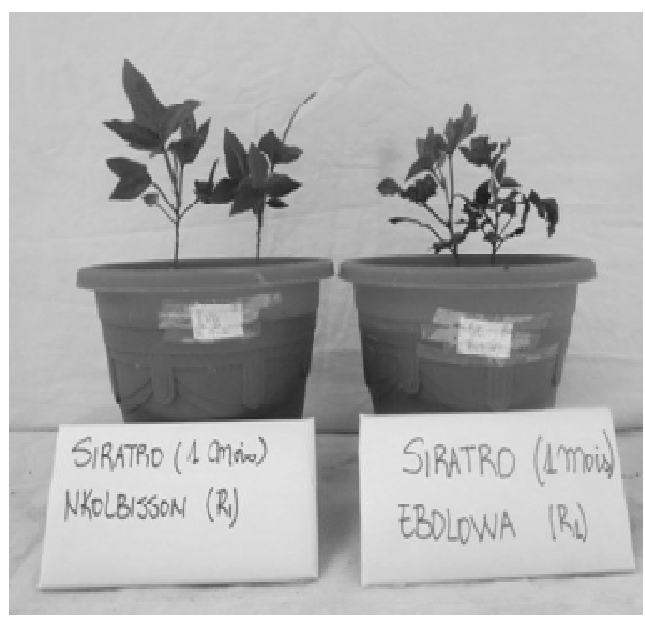

(1986). The different elements are expressed in SI units.

\section{Trapping of rhizobia}

Assays were performed in a greenhouse at the Experimental Station of the Institute for Agricultural Research and Development (IRAD) of Nkolbisson in the biological control and applied microbiology laboratory. An equivalent of $500 \mathrm{~g}$ of soil sample per treatment was used as a source of inoculums for rhizobial extraction. The soil was mixed with sterilized (autoclaved at $121^{\circ}$ C for 2 hours) sand (1:1 v/v) and added to sterile vessels (pots) with a capacity of $1000 \mathrm{~g}$ substrate. Pots were sown with 4 sterilized seeds of the trap plants and placed in greenhouse. The sterilization was performed by rinsing the seeds with $95 \%$ ethanol for 30 seconds, and with $0.2 \%$ sodium hypochlorite for 4 minutes and finally with sterile water to remove the hypochlorite solution. On the eighth day after germination, plants were thinned to two plants per pot. Plants were watered every morning with $500 \mathrm{ml}$ of sterile water to facilitate their growth (Fig. 1). The vessels received every 2 weeks a solution containing all nutrients except nitrogen (J ensen, 1942). For each plant species and soil type (Al toxic soil, Mn toxic soil, control soil), three (3) replications were performed in a factorial completely randomized block design, giving a total of 18 vessels. The plants were harvested at early stages of flowering (approximately 60 days after the onset of germination) for rhizobial screening.

sodium hypochlorite for 4 minutes and then washed with sterile water. Thereafter, the nodules were crushed in a sterile test tube and the mashes were spread on Petri dishes containing YMA (yeast mannitol agar) supplemented with bromothymol blue (BTB) or Congo red (CR) at $\mathrm{pH}$ 6.8. Plates were incubated at $30^{\circ} \mathrm{C}$ for 7 days 
to observe the grouth of the bacterial colonies. Colonies were transplanted into new plates containing the same medium and incubated again in the same conditions until the appearance of purified isolates. Isolates obtained were picked and stored at $4^{\circ} \mathrm{C}$ in eppendorf tubes containing $1.5 \mathrm{ml}$ of YMA buffered with $3 \mathrm{~g} / \mathrm{L}$ of CaCO3.

\section{Morphological characterization of isolates}

Morphological characterization was performed according to Vincent (1970) by evaluating the time of growth of each of the isolates on the medium to determine the slow and rapid growing bacteria, the $\mathrm{pH}$ of the medium after the bacterial growth observed indirectly by the color of the medium containing bromothymol blue (alkaline, acid and neutral), the shape of the colonies (round, irregular, or star). The type of mucus produced by the cells on the petri dishes was assessed. The YMA-CR medium served to determine the diameter and the shape of colonies while the YMA-BTB was mainly used to verify the ability of colonies to change the $\mathrm{pH}$ of the medium within 24 hours and to distinguish the rapid growing-bacteria (acidifying-bacteria leading to yellow color) to the slow-growers (alkaline-producing bacteria leading to blue color) as reported by Somasegaran and Hoben (1985).

\section{Molecular characterization of rhizobia}

The molecular study involved 40 selected isolates out of the total 120 extracted bacteria based on morphological observations. DNA was extracted according to the protocol described by Benhizia et al. (2004) and its concentration was assessed by electrophoresis on a $2 \%$ agarose gel $(w / v)$ pre- stained with ethidium bromide $(0.117 \mathrm{mg} / \mathrm{mL})$, before performing the 16S rDNA PCR reaction. These molecular analyses were performed at the Mediterranean and Tropical Symbioses Laboratory of Montpellier (LSTM in French). The 16S rDNA region of the bacterial genome was amplified using 2 primer sets: 27F/1953 R and FGPS6/ FGP1509.

Amplification reactions were performed in a $25 \mu \mathrm{l}$ reaction volume containing $1 \mu \mathrm{l}$ of $50 \mu \mathrm{g}$ of genomic DNA, $0.2 \mathrm{mM}$ dNTP mix, $1.5 \mathrm{mM}$ $\mathrm{MgCl}_{2}, 5 \mu \mathrm{l}$ of $10 \mathrm{X}$ Taq buffer, $1 \mathrm{U}$ Taq DNA polymerase, 10 pmoles of each primer and rest of the volume was adjusted by autoclaved pure water. Reactions were carried out in thermocycler. After denaturation at $95^{\circ} \mathrm{C}$ for 10 min, samples were cycled for 35 cycles through the following temperature profile: denaturation at $95^{\circ} \mathrm{C}$ for $30 \mathrm{sec}$, annealing at $58^{\circ} \mathrm{C}$ for $1 \mathrm{~min}$, extension at $72^{\circ} \mathrm{C}$ for $2 \mathrm{~min}$ and additional cycle for chain elongation at $72^{\circ} \mathrm{C}$ for $10 \mathrm{~min}$.

Amplified products from the second primer set FGPS6 (5'-GGAGAGTTAGATCTTGGCTCAG-3') and FGPS1509 (5'AAGGAGGGGATCCAGCCGCA-3') which gave the expected fragment of 1500 bp size (Fig. 2) were digested using the endonucleases Hind III and MspI. The restriction fragment length polymorphism (RFLP) profiles were visualized by gel electrophoresis on a 3\% agarose gel (w/v) prestained with ethidium bromide $(0.117 \mathrm{mg} / \mathrm{mL})$. The gels were run at $100 \mathrm{~V}$ for $3 \mathrm{~h}$ then visualized under UV illumination and photographed with an apparatus Gel Doc BIORAD.

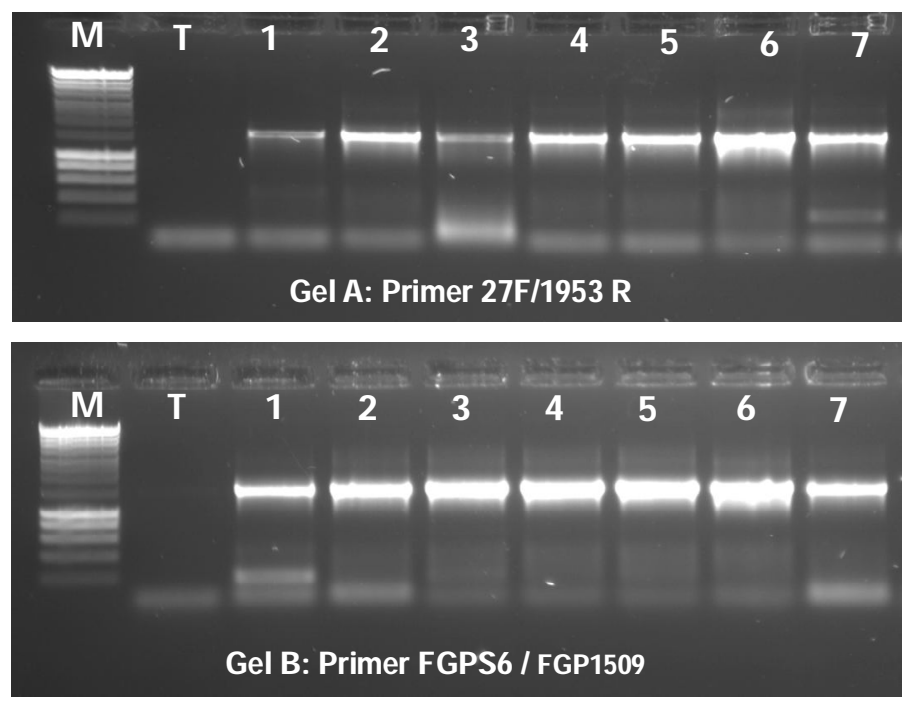

Fig. 2. $16 \mathrm{~S}$ rDNA PCR products of isolates M: $1 \mathrm{kbp}$ Ladder Marker, T: negative control. 7 samples were used to test the primers. PCR products from the primer FGPS6/FGP1509 (Gel B) with the expected size of $1500 \mathrm{bp}$ were used for digestion with the endonucleases Hind III and MspI. The primer 27F/ 1953R (Gel A) gives PCR products of 1950 bp size. 


\section{Data collection and statistical analy ses}

Plants were harvested 60 days after germination (DAS). In each pot, fresh shoots were separated from the fresh roots and their biomass was weighed to determine fresh weight. They were oven-dried at $70^{\circ} \mathrm{C}$ for 48 hours after which the dry weights were recorded. The chlorophyl content of plants during growth was estimated by non-destructive absorption according to Gitelson et al. (1999). The instrument to quantify the chlorophyll named CCM 300 chlorophyll content meter uses a fluorescence excitation wavelength with a peak at $460 \mathrm{~nm}$ and a half band width of 15 $\mathrm{nm}$. It measures two different emission wavelength ranges at the same time, $730 \mathrm{~nm}$ to $740 \mathrm{~nm}$, and $698 \mathrm{~nm}$ to $708 \mathrm{~nm}$. Fresh and dry plant yields were entered to Excel and analyzed together with other agronomic parameters such as the number of nodules, diameter of nodules, root length, and chlorophyll. Statistical analyses of the data were carried out using the CropStat 7.2 software (IRRISTAT). Parameters recorded for each plant were analyzed separately, using one-way ANOVA and where the variable was the soil type. Whenever significant $(\mathrm{P}<0.05)$, least significant difference (LSD) was used to separate the means of treatments.

\section{Results}

\section{Physico-chemical characteristics of Nkoemvone and Nkolbisson soils}

Soil physico-chemical characteristics of the two sites used for rhizobial trapping are presented in Table 1. Essential soil nutrients with the exception of $\mathrm{Al}$ and $\mathrm{Mn}$ have an acceptable value for plant's growth. The $\mathrm{pH}$ which is lower than 5.2 indicates acidic soils, contrasting in their $\mathrm{Al}$ and Mn toxicities. The soil in the Nkoemvone site is characterized by aluminum toxicity (4.46-fold of that of Nkolbisson's soil) while the Nkolbisson soil is manganese-toxic (13.96-fold of that of Nkoemvone's soil). Moreover, the two soils clearly show low nitrogen content. The total $\mathrm{N}$ and total carbon concentrations did not significantly differ between the two types of sites. The soil $\mathrm{C} / \mathrm{N}$ ratio of the Nkolbisson site (13.86) was slightly higher than that of Nkoemvone site (9.28). A low $\mathrm{C} / \mathrm{N}$ ratio suggests a high activity of microorganisms. The concentrations of available phosphorus and potassium in the soils were not significantly different between the 2 sites. Little differences were found between the two sites for some soil characteristics such as the EC, CEC, and TSA. It appears that Nkolbisson soil displays a higher Fe content; and essential element in the rhizobia-legume symbiosis and $\mathrm{N}_{2}$-fixation.

Table 1. Physico-chemical characterization of Nkoemvone and Nkolbisson soils.

\begin{tabular}{lcc}
\hline Soils Characteristics & Nkoemvone (Ebolowa) & Nkolbisson (Yaounde) \\
\hline $\mathrm{Ca} \mathrm{mmol} / \mathrm{kg}$ & 6.8 & 26.8 \\
$\mathrm{Mg} \mathrm{mmol} / \mathrm{kg}$ & 2.0 & 7.2 \\
$\mathrm{~K} \mathrm{mmol} / \mathrm{kg}$ & 2.4 & 2.4 \\
$\mathrm{Na} \mathrm{mmol} / \mathrm{kg}$ & 1.3 & 0.4 \\
$\mathrm{Al} \mathrm{\mu mol} / \mathrm{kg}$ & $\mathbf{2 3 2 0 0}$ & 5200 \\
$\mathrm{Zn} \mathrm{mol} / \mathrm{kg}$ & 8.15 & 72.36 \\
$\mathrm{Cu} \mathrm{\mu mol} / \mathrm{kg}$ & 27.54 & 48.32 \\
$\mathrm{Mn} \mathrm{nmol} / \mathrm{kg}$ & 118130 & $\mathbf{1 6 4 9 0 8 8}$ \\
$\mathrm{Fe} \mathrm{\mu mol} / \mathrm{kg}$ & 2029.5 & 7424.7 \\
$\mathrm{Bray} \mathrm{P} \mathrm{mmol} / \mathrm{kg}$ & 0.244 & 0.15 \\
Org C (g/kg) & 11.3 & 18.1 \\
Total N $(\mathrm{g} / \mathrm{kg})$ & 1.21 & 1.32 \\
$\mathrm{C} / \mathrm{N}$ & 9.28 & 13.86 \\
$\mathrm{pH}$ & 4.33 & 5.12 \\
$\mathrm{EC}(\mathrm{uS} / \mathrm{cm})$ & 82.40 & 54.16 \\
$\mathrm{CEC} \mathrm{mmol} / \mathrm{kg}$ & 34.6 & 94.3 \\
TSA $(\%)$ & 32.74 & 39.02 \\
Type of toxicity & Aluminum toxicity & Manganese toxicity \\
\hline
\end{tabular}

\section{Effect of soil type on nodulation and growth of siratro and cowpea}

Data on growth and nodulation of siratro and cowpea were collected in order to have a general idea about the overall biodiversity of the studied soils. Data on the nodulation and growth of siratro as influenced by soil type are reported in Table 2. Results show no significant difference of siratro's nodule number per plant, fresh and dry weights of aerial system, and chlorophyll content. The fresh weights of siratro's root system and nodules were higher when the plant is grown using Nkolbisson soil. However, the root length of siratro in the Nkolbisson soil was shorter than that in the control soil. On the other hand, significant differences were observed for the characteristic of siratro between the aluminumtoxic Nkoemvone soil and the control, where the 
Nkoemvone soil displayed lower values except for the chlorophyll content. Considering the effect of Nkolbisson and Nkoemvone soils, all siratro's characteristics were significantly higher when the plant was grown using the Nkolbisson soil, except the chlorophyll content, which was higher in the Nkoemvone soil. Moreover, no significant difference was observed for the root length between the two soils.

Table 2. Effect of soil origin on nodulation and growth of siratro.

\begin{tabular}{|c|c|c|c|c|c|c|c|c|}
\hline \multirow[t]{2}{*}{ Soil origin } & \multirow{2}{*}{$\begin{array}{l}\text { Nod. } \\
\text { Numb. } \\
\text { Plant }^{-1}\end{array}$} & \multirow{2}{*}{$\begin{array}{l}\text { Nod. } \\
\text { Diam. } \\
\text { cm }\end{array}$} & FWAS & DWAS & FWRS & Nod. FW & \multirow{2}{*}{$\begin{array}{l}\mathrm{RL} \\
\mathrm{cm}\end{array}$} & \multirow{2}{*}{$\begin{array}{c}\text { Chlor. } \\
\%\end{array}$} \\
\hline & & & \multicolumn{4}{|c|}{ g pot $^{-1}$} & & \\
\hline Nkolbisson & $3.67 \mathrm{~b}$ & 0.97 & $0.95 \mathrm{~b}$ & $0.54 \mathrm{~b}$ & $0.34 \mathrm{C}$ & $0.120 \mathrm{c}$ & $14.05 a$ & $14.04 \mathrm{a}$ \\
\hline Nkoemvone & $0.67 a$ & 1.07 & $0.60 \mathrm{a}$ & $0.27 a$ & $0.13 a$ & $0.007 a$ & $13.47 \mathrm{a}$ & $24.81 \mathrm{~b}$ \\
\hline Control & $2.17 \mathrm{~b}$ & 1.02 & $1.05 \mathrm{~b}$ & $0.55 \mathrm{~b}$ & $0.19 \mathrm{~b}$ & $0.063 \mathrm{~b}$ & $19.08 \mathrm{~b}$ & $13.45 \mathrm{a}$ \\
\hline Sign. Trait $\left(\mathrm{P}_{0.05}\right)$ & $*$ & ns & $*$ & $*$ & ** & & & \\
\hline
\end{tabular}

The Table 3 shows the results of cowpea nodulation and growth as influenced by the soil type. Values of the nodule number per plant, fresh and dry weights of aerial system, fresh weight of root system, and root length of cowpea were significantly higher in the control soil compared to the Nkolbisson soil. Comparing the effect of Nkoemvone and control soils, cowpea grown in Nkoemvone soil showed significant lower fresh weights of aerial system and root system, root length and chlorophyll content. However, the nodule number per plant and the dry weight of aerial system were significantly higher in the Nkoemvone soil. On the other hand, cowpea characteristics were significantly lower in the Nkolbisson soil compared to that in the Nkoemvone soil, except the non-significant difference observed for the root length between the two soils, and the higher chlorophyll content in the Nkolbisson soil. A closer observation shows higher cowpea fresh weights of root system than fresh weights of aerial system in the Nkoemvone and control soil. This is likely due to important loss of leaves during the experiment. The Figure 1 confirms an overall higher cowpea foliage development in Nkoemvone soil than in Nkolbisson soil after one month of culture, while siratro grows better with the Nkolbisson soil.

Table 3. Effect of soil origin on nodulation and growth of cowpea.

\begin{tabular}{|c|c|c|c|c|c|c|c|c|}
\hline \multirow[t]{2}{*}{ Soil origin } & $\begin{array}{l}\text { Nod. } \\
\text { Numb. }\end{array}$ & $\begin{array}{l}\text { Nod. } \\
\text { Diam. }\end{array}$ & FWAS & DWAS & FWRS & Nod. FW & $\mathrm{RL}$ & Chlor. \\
\hline & Plant $^{-1}$ & $\mathrm{~cm}$ & \multicolumn{4}{|c|}{$\mathrm{g} \mathrm{pot}^{-1}$} & $\mathrm{~cm}$ & $\%$ \\
\hline Nkolbisson & $01.00 \mathrm{a}$ & 0.73 & $1.34 \mathrm{a}$ & $0.60 \mathrm{a}$ & $00.63 a$ & $0.003 a$ & $15.37 a$ & $24.13 \mathrm{~b}$ \\
\hline Nkoemvone & $13.67 \mathrm{c}$ & 2.30 & $3.87 \mathrm{~b}$ & $2.35 c$ & $08.77 \mathrm{~b}$ & $0.060 \mathrm{~b}$ & $14.42 \mathrm{a}$ & $13.91 \mathrm{a}$ \\
\hline Control & $07.33 \mathrm{~b}$ & 1.52 & $8.10 \mathrm{c}$ & $2.00 \mathrm{~b}$ & $15.14 \mathrm{C}$ & $0.032 \mathrm{ab}$ & $33.83 \mathrm{~b}$ & $23.18 \mathrm{~b}$ \\
\hline Sign. Trait $\left(\mathrm{P}_{0.05}\right)$ & $*$ & ns & $* *$ & ** & ** & $*$ & $*$ & $*$ \\
\hline
\end{tabular}

Nod. Numb: nodule number, Nod. Diam.: nodule diameter, FWAS: fresh weight of aerial system, DWAS: dry weight of aerial system, FWRS: fresh weight of root system, Nod. FW: nodule fresh weight, RL: root length, Chlor: chlorophyll, Sign. Trait: significant trait at 5\% probability level, ns: non-significant, *: significant at P $\leq$ 0.05 , **: significant at $\mathrm{P} \leq 0.01$. Statistical analysis was performed using CropStat 7.2 and in a column, mean values ( 3 repetitions) followed by different letters $(\mathrm{a}, \mathrm{b})$ are significantly different at the indicated significant level.

\section{Morphological characterization of nodules and bacterial isolates}

120 nodules were collected from the two host plants used in the trapping of rhizobia. Most nodules presented more a less round shape with bulges on either side. All isolates were subjected to Gram staining and microscopic observations showed that they were all Gram negative. Approximately, the majority of rhizobial isolates had the same colony morphology and the same growth rate on YMA medium. A high production of mucus (exopolysaccharide) was verified in $81 \%$ of the studied isolates. They formed transparent to creamy colonies with 2 to $4 \mathrm{~mm}$ in diameter after 1 to 3 days incubation on YMA plates. Forty isolates (20 per site) representing the various morphologies and physical characteristics were obtained. Physical characteristics of colonies on
YMA plates showed a lot of similarities between the two sites. Based on the physical characteristics, the isolates of each site were classified into five large groups (Table 4). From each site, the isolates comprised slow-growing and fast-growing bacteria. On YMA-BTB plates, the fast growing bacteria (acid-producing) color the medium in yellow while slow-growers (alkaline-producing) color the medium in bluegreen. In this study, approximately $58 \%$ of isolates recovered from the Nkoemvone soil showed a rapid growth in the culture medium in comparison to the $75 \%$ of fast-growing isolates obtained from the Nkolbisson soil. The consistency of the mucus produced on YMA plates quite varied among isolates. Fast-growing isolates generally presented viscous mucus while slow-growers had butyric mucus. The colonies 
appeared with different textures corresponding to milky, sticky and whitish. The texture was regardless to the growth speed of colonies on YMA plates as fast-growing isolates could either be milky or sticky or whitish. For isolates with a milky texture and mucus that leaches across the plate, it is difficult to isolate a colony after few days. Furthermore, both slow and fast-growing isolates could be either flat or entirely pulvinate. The shapes of the colonies on YMA plates were roughly variables with the most dominants being: star, round and irregular, and is dependent on the presence of mucus. The diameter of colonies varied between 2 to $4 \mathrm{~mm}$.

Table 4. Morphological characteristics of the groups of Rhizobial isolates collected from central (Yaounde-Nkolbisson) and southern (Ebolowa-Nkoemvone) soils of the humid forest zone of Cameroon.

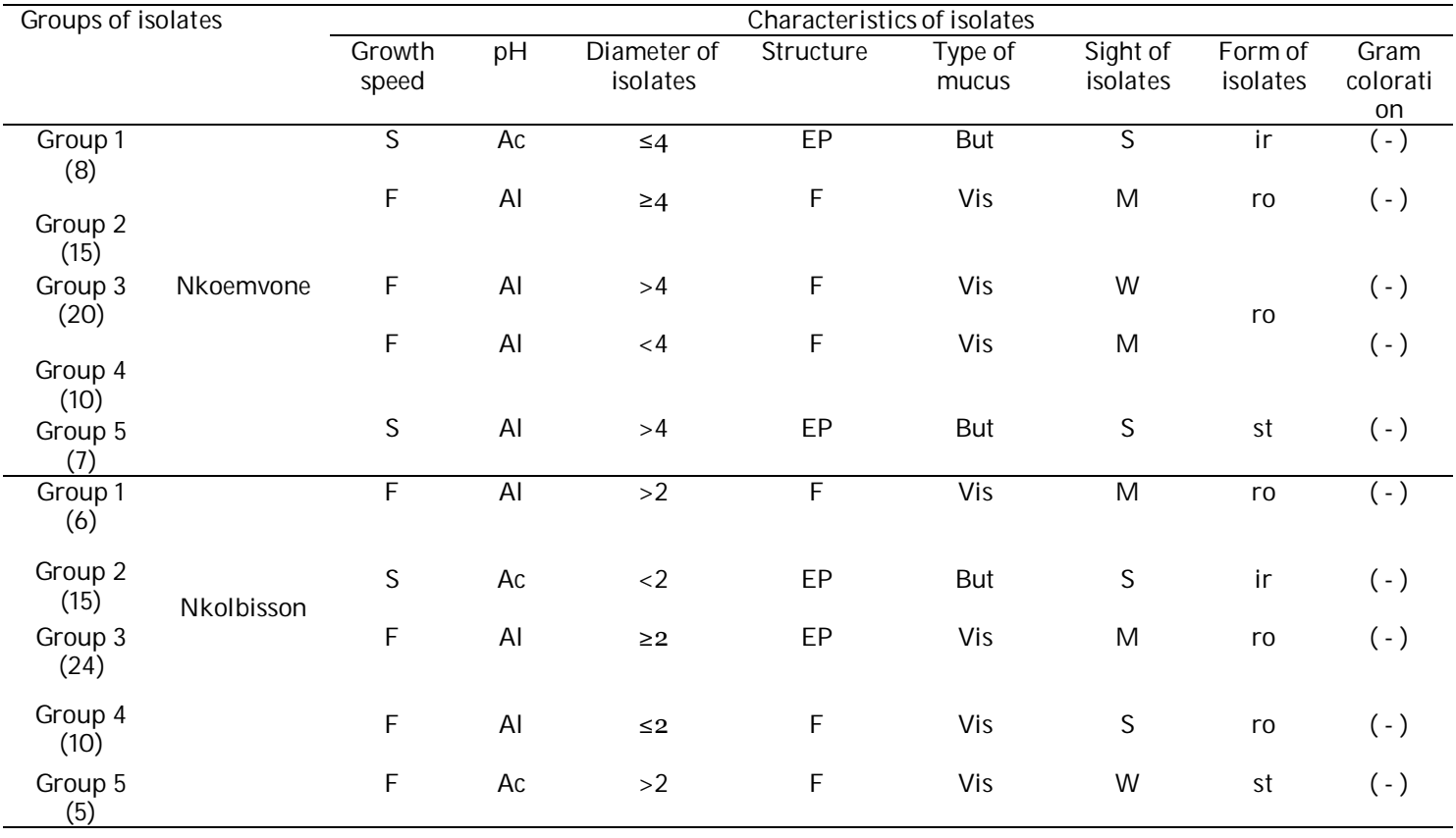

Growth speed (F: fast $\leq 3$ days; S: slow $\geq 3$ days);pH of the medium (Ac: acid; Al: alkaline); Diameter of isolates in mm; Structure of colonies ( F: flat; EP: entirely pulvinate); Type of mucus (Vis: Viscous; But: butyric); Sight of isolates ( M: milky; S:sticky; W:whitish); Form of isolates (ro: round; ir: irregular; st: star ); gram coloration: negative gram (-)

PCR-RFLP based molecular characterization of isolates

Based on the results of the morphological test, the 40 most representative isolates were chosen for further molecular characterization. The Figure 2 shows the electrophoresis profiles of some isolates following the first PCR amplification with the primer set 17F/1953R that yielded $1950 \mathrm{bp}$ fragments and the second amplification with the primer set FGPS6/FGP1509 giving fragments of 1500 bp size. The amplified 16S rDNA PCR products of the second reaction were restricted by the endonucleases Hind III and MspI according to the manufacturer's instructions to produced RLFP. The restricted fragments were analyzed by agarose gel (3\%) electrophoresis and visualized under UV light after ethidium bromide staining. The restriction by both enzymes gave rise to several bands of different sizes corresponding to the number of specific sites encountered in the sequence of the 16S rDNA (Fig. 3). The restriction profiles obtained with the Hind III enzyme were similar for some isolates, although the isolates with identical rDNA genotypes did not display similar phenotypic characteristics. For the Nkoemvone site, ten isolates $(1,3,5,6,7,9,10,11$ $16,17)$ produce an identical profile, while for the remaining ten isolates, two isolates $(14,19)$ have an identical profile; four isolates $(2,12,13,18)$ have different profiles and the other four isolates $(4,8,15,20)$ are removed during the PCR. At the Nkolbisson site, the restriction by the Hind III enzyme leads to a set of six isolates $(22,26,28,31$, 36,38 ) with an identical profile, four profiles are identical two by two (35-37, 32-33), seven profiles $(21,23,24,25,27,30,39)$ are different and the other three isolates $(29,34,40)$ are removed during the PCR. A control without DNA is included to ensure that the samples are free of contamination. The restriction fragments of the 16S rDNA using Hind III gives 6 different genotypic groups for the Nkoemvone site and 10 different genotypic groups for the Nkolbisson site (Figure3). In the Nkoemvone site, the genotype 
"a" is mostly represented with $53 \%$ of all genotypes. In the Nkolbisson site, the type "b" is dominant with $36 \%$ of all genotypes. Overall, the

\section{Nkoemvone $\left(\mathrm{Al}^{3+}\right)$}
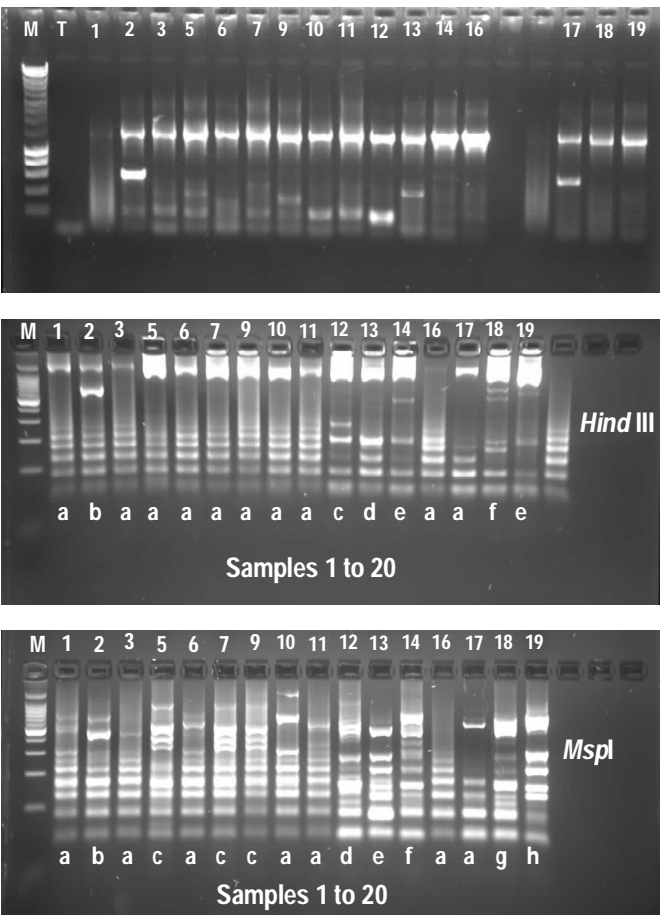

restriction enzyme Hind III grouped the isolates into 10 different groups for the 2 sites.

\section{Nkolbisson $\left(\mathrm{Mn}^{2+}\right)$}
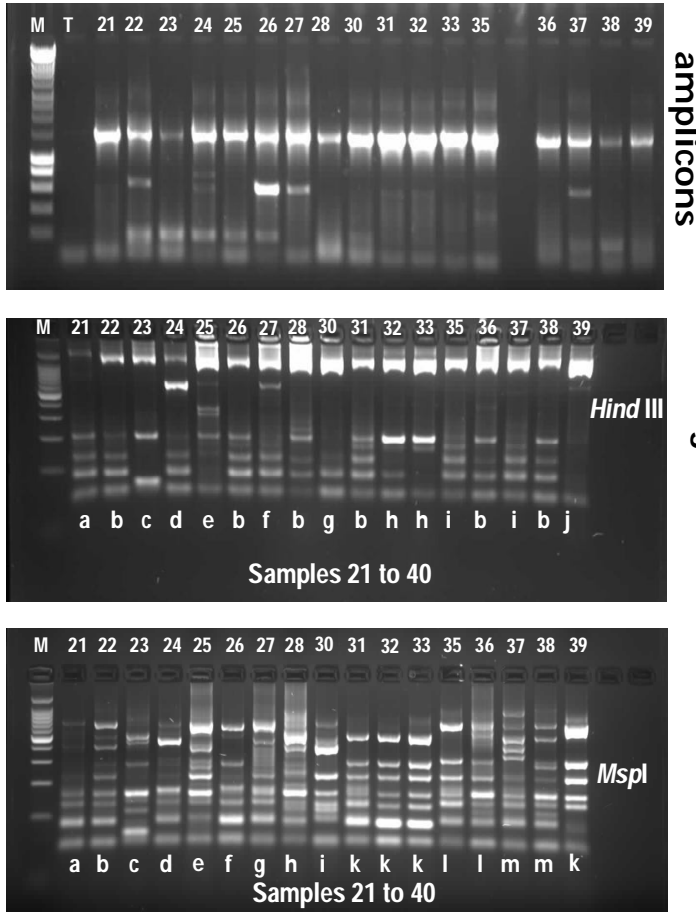

Fig. 3. Genetic profiles of isolates generated by Hind III and Msp I endonucleases M: 100 bp Ladder Marker, T: negative control. The RFLP shows 8 genotypic groups at Nkoemvone with the dominance of the "a" type with $43.75 \%$, and 12 genotypic groups at Nkolbisson with the dominance of the type " $\mathrm{k}$ " at $23.52 \%$. In the 2 gels (both sites) given by each endonuclease, identical letters "a, b, c, d, e, f, g, h, i, $\mathrm{k}, \mathrm{l}, \mathrm{m}$ " show a similar genotype.

Comparatively to the Hind III enzyme, restrictions with Msp I of the Nkoemvone isolates give seven isolates $(1,3,6,10,11,16,17)$ with similar band pattern, three others $(5,7,9)$ shared the same phenotype, and six isolates $(2,12,13,14$, 18 , 19) were different from one another. Three isolates $(4,8$, and 20$)$ were however removed during the PCR. In the Nkolbisson site, one set of four isolates (35-36, 37-38) shows a similar band pattern, and another set of four isolates (31, 32, $33,39)$ has a common profile. The band patterns of nine isolates $(21,22,23,24,25,26,27,28$, and 30) are different from one another and from the two first groups. Three isolates $(29,34,40)$ were removed during the PCR. Therefore, the restriction fragments of 16S rDNA using MspI gives 8 different genotypic groups for the Nkoemvone site and 12 different genotypic groups for the Nkolbisson site (Fig. 3). In the Nkoemvone site, the genotype "a" is mostly represented with $37 \%$ of all genotypes from 1 to 20 . On the other hand, in the Nkolbisson site, the type " $\mathrm{k}$ " is dominant with $24 \%$ of all genotypes from 20 to 40 . Thus, it is clear from this analysis that the MspI restriction enzyme gives a better profile diversity of 12 different genotypic groups as shown in Table 5. 
Table 5. Distribution of isolates in the 2 soils.

\begin{tabular}{ccc}
\hline Types of & & Sites \\
\cline { 2 - 3 } isolates & Nkoemvone (Ebolowa) & Nkolbisson (Yaounde) \\
\hline $\mathrm{a}$ & 7 & 1 \\
$\mathrm{~b}$ & 1 & 1 \\
$\mathrm{c}$ & 3 & 1 \\
$\mathrm{~d}$ & 1 & 1 \\
$\mathrm{e}$ & 1 & 1 \\
$\mathrm{f}$ & 1 & 1 \\
$\mathrm{~g}$ & 1 & 1 \\
$\mathrm{~h}$ & 1 & 1 \\
$\mathrm{i}$ & 0 & 1 \\
$\mathrm{k}$ & 0 & 4 \\
$\mathrm{l}$ & 0 & 2 \\
$\mathrm{~m}$ & 0 & 2 \\
\hline Total & 16 & 17 \\
\hline
\end{tabular}

The letters “a, b, c, d, e, f, g, h, i, k, l, m" show the different types of genotypes in both sites and the number beside the column show representatively of theses genotypes.

Analysis of the diversity of rhizobia associated with cowpea and siratro in the two sites showed a certain variation in the constitution of the groups. In one hand, the genotypes $\mathrm{a}, \mathrm{b}, \mathrm{c}, \mathrm{d}, \mathrm{e}, \mathrm{f}, \mathrm{g}$ and $\mathrm{h}$ are commonly found in the two sites (irrespective

\section{Discussion}

Soil acidity is a major constraint to agricultural production, especially intemperate and tropical regions where high precipitations influence the pedogenic development of soils. In Cameroon, the low soil fertility is a leading constraint to crop production. Soil fertility can be maintained or improved by a combination of several factors such as the application of manure, composting, mulching, liming and the use of inorganic fertilizers. However, the use of inorganic fertilizers and the maintenance of soil health have neither been generally widespread nor consistent due to patterns of land use and agricultural governance. Moreover, the economic constraints limit the use of inorganic fertilizers for a majority of small-scale farmers. Low soil $\mathrm{pH}$ has strong effects on the availability of most nutrients as it affects the chemical forms and the solubility of nutrient elements and influences the diversity of soil microbial population. The primary problems related to soil acidity in the humid forest zone are aluminum and manganese toxicities and deficiencies of $\mathrm{Ca}, \mathrm{Mg}$ and Mo. Both toxicities, if not prevented, may cause severe damage to the crop and crop yield (Slattery et al., 1999). Aluminum is present in all soils, but dissolved $\mathrm{Al}^{3+}$ is toxic to plants. Aluminum toxicity inhibits root development and limits crop growth. This is confirmed by the results of root length, root and aerial systems of siratro and cowpea in this study (Table 2, Table 3). In our study, the Al toxicity drastically reduces the nodulation phenotype of siratro but seems to not affect that of cowpea, to the plant). In another hand, the genotypes I, $\mathrm{k}$, $\mathrm{l}$ and $\mathrm{m}$ are specific to Nkolbisson; suggesting that the distribution of the strains varies according to the soil type (Table 5).

although cowpea growth was reduced. Manganese toxicity symptoms include yellowish older leaves (chlorosis) with brown spots. Farmers may reduce manganese toxicity by liming and aerating fields. Interestingly, the Mn toxicity did not negatively affect the nodulation phenotype and growth of siratro (Table 2), except that it significantly reduced the root length. A contrasting result was observed for cowpea which displayed significant lower nodulation and growth when grown using the manganese-toxic Nkolbisson soil. These observations indicate that Al toxicity affects both plants while siratro seems to adapt to manganese-toxic soils. This is in agreement with Philpotts (1975) who tested the effect of manganese toxicity on the nodulation and growth of glycine and siratro, where siratro appeared to be less sensitive to the toxicity. In our study, cowpea response to manganese toxicity is more pronounced than that of aluminum toxicity. In low $\mathrm{pH}$ soils, microbial populations are reduced, resulting in a reduced capacity to degrade organic matter. Consequently, such soils are more loosely held together and are more likely to be degraded through external influences such as high rainfall events, drought and agricultural disturbance of the soil. While soil acidity limits the survival and growth of rhizobia (Andrade et al., 2002), elevated levels of aluminum have been shown to directly affect the nodule initiation and the nitrogen fixation process (Slattery et al., 2001). In the root, Al has been shown to interfere with many physiological processes including the uptake and transport of 
calcium and other essential nutrients, cell division, cell wall formation, and enzyme activity (Iqbal, 2012).

Our study assessed the rhizobial diversity in the forest zone of Cameroon through phenotypic and genotypic characterizations. In this study, a high diversity of rhizobial strains was found nodulating cowpea and siratro, and this corroborates several studies that show a high heterogeneity in the populations of legumenodulating rhizobia (Sarr et al., 2009). Most of the isolates in this study were able to produce mucus, which might protect them to withstand temperature and $\mathrm{pH}$ fluctuations. Acidity changes the soil microbial community and decreases root and rhizosphere effects. This reduces the positive effect of the microbial communities and increases the reliance on fertilizers to sustain any form of productive agriculture. According to microbehost specificity, rhizobia isolated from cowpea are generally placed in the cowpea-cross-inoculated group and species of this heterogeneous group were assigned, based on phylogenetic, to the genus Bradyrhizobium (J ordan, 1984; Sarr et al., 2009). On another hand, Siratro is a leguminous crop nodulated in its root system by all types of specific rhizobia in tropical soils with $70 \%$ of fast growing and $30 \%$ of slow growing rhizobia (Mwenda et al., 2011). However, the diversity of rhizobia obtained in our study may have been limited by the presence of toxic elements such as aluminum (Nkoemvone site) and manganese (in Nkolbisson site) at relatively high doses (Table 1). Indeed, it seems that the soil composition in some elements could have a selective effect on the diversity of rhizobia associated with cowpea. Cheng (2003) indicated that physicochemical properties of the soil affect the availability of rhizobia. Soil acidity and aluminum toxicity contribute to the reduction of diversity of rhizobial populations in tropical soils (Andrade et al., 2002). In the two studied sites, different bacterial genotypes were found, following PCRRFLP with the restrictions enzymes Hind III and MspI. The results show that the MspI restriction enzyme is a discriminate enzyme that digests all isolates, generating many bands and grouping the rhizobia isolates into 12 different genotypic groups (Table 5). This result shows that under stressful environmental conditions, rhizobia seem to accommodate to the soil conditions. Graham et al. (1994) indicated that the tolerance of rhizobia to alkaline and acid soils remains ambiguous. However, Chen et al. (1993) showed that the cytoplasmic $\mathrm{pH}$ of acid-tolerant strains is less strongly affected by the external acidity. The works of Dilworth et al. (2000) as reported by Ferguson et al. (2013) revealed that certain types of rhizobia survive to acid soils. Indeed, high soil acidity conditions affect all the stages of the symbiosis, from the survival of the strain sin the soil to the infection process, nodulation and nitrogen fixation (Ferguson et al., 2013). In acidic conditions, the formation of nodules is reduced by $50 \%$ for cowpea and acidic $\mathrm{pH}$ disrupts the signal exchange between the host plant and the bacterium in the establishment of the symbiosis; reducing the secretion of flavonoids by plants and the induction of Nod genes in bacteria (Alva et al., 1990). Similar results relating to the heterogeneity in the proportion of rhizobia have already been demonstrated by Hartel and Alexander (1983) and Coventry and Evans (1989). This contrasted with the result obtained in our study where cowpea nodulation was higher in the Al-toxic Nkoemvone soil compared to the control. Further investigations are necessary to clarify this result.

\section{Conclusions}

Our results show that the study of the diversity of rhizobia depends on the plant host and the physico-chemical composition of the soil. The restriction pattern of the 16S rDNA of the isolates from the 2 soils showed 12 different genotypes. Eight (8) were present in the 2 soils, while four were specific to the acidic soil with manganese toxicity. This study revealed the distribution of rhizobia based on soil characteristics. However, this diversity might have been under estimated by the trapping-isolation method. The trapping method is not optimal to isolate the entire diversity of symbiotic strains associated with a plant, mainly because of the competition between strains for nodulation; with the most competitive strains invading in first order the plant host. Moreover, it would be interesting to assess the efficiency of the strains to fix nitrogen in the presence of the main toxic elements such as aluminum and manganese. Further molecular analyses would allow the identification of the isolates recovered as well as their phylogenetical relationships.

\section{Acknowledgments}

We would like to thank University of Yaounde I, Institute of Agricultural Research for Development (IRAD) and Laboratory of Tropical and Mediterranean Symbioses (LSTM), for their efforts in making this work possible. We also would like to thank Mr. Owona Alexis, the research technician of the IRAD Nkolbisson Institution, for his valuable support during the work. We also acknowledge Prof. Bell Martin J oseph of Yaounde I University and Dr. Kuate Jean at the Laboratory of Biological Control and Applied Microbiology for their collaboration during the work. 


\section{References}

Alva, A., Asher, C. and Edwards, D. 1990. Effect of solution $\mathrm{pH}$, external calcium concentration and aluminum activity on nodulation and early growth of cowpea. Aust. J. Agric. Res. 41: 359-365.

Anderson, J.M. and Ingram, J.S. 1993. Tropical soil biology and fertility: a handbook of methods. 2nd ed. CAB International Wallingford, UK. $221 \mathrm{p}$.

Andrade, D.S., Murphy, P.J . and Giller, K.E. 2002. Effects of liming and legume/ cereal cropping on populations of indigenous rhizobia in an acid Brazilian Oxisol. Soil Biol. Biochem. 34: 477-485.

Barnhisel, R. and Bertsch, P. 1982. Aluminum. In: Page, A., Miller, R., Keeney, D. (eds.). Methods of Soil Analysis, Part 2, Chemical and Microbiological Properties. American Society of Agronomy, Madison, Wisconsin, USA. pp. 275-300.

Benhizia, Y., Benhizia, H., Benguedouar, A., Muresu, R., Giacomini, A. and Squartini, A. 2004. Gamma proteobacteria can nodulate legumes of the genus Hedysarum. Syst. Appl. Microbiol. 27: 462 -468.

Bindzi-Tsala, J. 1987. Les sols rouges du Cameroun. Communication, huitième réunion du sous-comité Ouest et Centre Africain de corrélation des sols pour la mise en valeur des Terres. MINREST-FAO, Yaoundé, Cameroun. p. 10.

Black, C.A. 1982. Methods of Soil Analysis. Agronomy, No. 9, Part 2, American Society of Agronomy \& Soil Science Society of America, Madison, Wisconsin. Vol. 9, pp. 539-579.

Brady, N.C. and Weil, R.R. 2002.The nature and properties of soils. Prentice Hall, New York, USA. p. 208.

Bray, R.H. and Kurtz, L.T. 1945. Determination of total organic and available forms of phosphorus in soils. Soil Sci. 59: 39-45.

Buondonno, A., Rashad, A.A and Coppola, E. 1995. Comparing tests for soil fertility the hydrogen peroxide/sulfuric acid treatment as an alternative to the copper/selenium catalyzed digestion process for routine determination of soil nitrogen-Kjeldahl. Com. Soil Sci. Plant Anal. 26: 1607-1619.

Chen, H., Richardson, A.E. and Rolfe, B.G. 1993. Studies of the Physiology and Genetic Basis of Acid Tolerance in Rhizobium leguminosarum biovartrifolii. Appl. Environ. Microbiol. 59: 1798-1804.

Cheng, Y. 2003. Plant mechanisms contributing to acid impairment of nodulation of Medicago murex and Medicago sativa by Sinorhizobiummedicae. $\mathrm{PhD}$ Dissertation, University of Western Australia. p. 180.
Coventry, D.R. and Evans, J. 1989. Symbiotic nitrogen fixation and soil acidity. In: Robson, A.D. (ed.). Soil Acidity and Plant growth. Academic Press Australia, Sydney, Australia. pp.103-137.

Dilworth, M.J., Tiwari, R.P., Reeve, W.G. and Glenn, A.R. 2000. Legume root nodule bacteria and acid pH. Sci. Progress 83: 357389.

Domergue, O. 2006. Diversité des rhizobia associés à Ononis repens: une légumineuse adaptée aux milieux méditerranéens. Mémoire pour l'obtention du Diplôme de l'École Pratique des Hautes Études. Montpellier, France. p. 19.

Dommergues, Y.R. and Krupa, S.V. 1978. Interactions between non-pathogenic soil microorganisms and plants. Dev. Agric. Managed-Forest Ecol. 4: 335-372.

Duponnois, R., Hafidi, M., Wahbi, S., Sanon, A., Galiana, A., Baudoin, E., Sanguin, H., Bâ, A.M., Prin, Y. and Bally, R. 2012. La symbiose mycorhizienne et la fertilité des sols dans les zones arides:un outil biologique sous-exploité dans la gestion des terres de la zone sahélo-saharienne. In: Dia, A. (ed.). La Grande Muraille Verte: capitalisation des recherches et valorisation des avoirs locaux (Syntheses). Marseille, France. pp. 351-369.

Elliott, G.N., Chou, J.H., Chen, W.M., Bloemberg, G.V., Bontemps, C., Martinez-Romero, E., Velazquez, E., Young, J.P.W., Sprent, J.I. and James, E.K. 2009. Burkholderia spp. are the most competitive symbionts of Mimosa, particularly under N-limited conditions. Environ. Microbiol. 11: 762- 778.

Elmerich, C. 1993. Fixation biologique de l'azote. Ann. Inst. Past. 4: 133- 153.

Ferguson, B.J., Harlin, M. and Gresshoff, P.M. 2013. Regulation of legume nodulation by acidic growth conditions. Plant Signal Behav. 8(3): e23426.

Gehlot, H.S., Tak, N., Kaushik, M., Mitra, S., Chen, W.M., Poweleit, N., Panwar, D., Poonar, N., Parihar, R., Tak, A., Sankhla, I.S., Ojha, A., Rao, S.R., Simon, M.F., dos Reis Junior, F.B., Perigolo, N., Tripathi, A.K., Sprent, J.I., Young, J.P.W., J ames, E.K. and Gyaneshwar, P. 2013. An invasive Mimosain India does not adopt the symbionts of its native relatives. Ann. Bot. 112(1): 179-196.

Gitelson, A.A., Buschmann, C. and Lichtenthaler, H.K 1999. The Chlorophyll Fluorescence Ratio F735/ F700 as an Accurate Measure of Chlorophyll Content in Plants. Remote Sens. Environ. 69: 296-302.

Graham, P.H., Draeger, K.J., Ferrey, M.L., Conroy, M.J., Hammer, B.E., Martinez, E., Arons, S.R. and Quinto, C. 1994. Acid pH tolerance in strains of Rhizobium and Bradyrhizobium and initial studies on the 
basis for acid tolerance of Rhizobium tropici UMR1899. Canadian J. Microbiol. 40: 189207.

Gyaneshwar, P., Hirsch, A.M., Moulin, L., Chen, W.M., Elliott, G.N., Bontemps, C., Estradade Los Santos, P., Gross, E., Dos Reis, F.B., Sprent, J.I., Young, J.P. and James, E.K. 2011.

Legume-nodulating betaproteobacteria: diversity, host range, and future prospects. Mol. Plant Microbes Interact. 24(11): 1276-1288.

Hartel, P.G. and Alexander, M. 1983. Growth and survival of cowpea rhizobia in acid aluminum-rich soils. Soil Sci. Soc. Am. J . 47: 502-506.

Heanes, D.L. 1984.Determination of organic C in soils by an improved chromic acid digestion and spectrophotometric procedure. Com. Soil Sci. Plant Anal. 15: 1191-1213.

Iqbal, M.T. 2012. Acid tolerance mechanisms in soil grown plants. Malay. J . Soil Sci. 16: 1-21.

Jensen, H.L. 1942. Nitrogen fixation in leguminous plants. Proc. Int. Soc. NSW, 66: 68-108.

J ordan, D.C. 1984. Family III.Rhizobiaceae. pp. 234-242. In: Krieg, N.R., Holt, J.C. (eds.). Bergey's Manual of Systematic Bacteriology. Williams and Wilkins Co., Baltimore, USA.

Kamdje, A., Bidjang, N. and Bonda, R. 1986. Observations bioclimatiques de la Station IRAD de Nkoemvone pour les années 19831984 et 1985-1986, IRAD, Yaounde, Cameroon.

Lemaire, B., Dlodlo, O., Chimphango, S., Stirton, C., Schrire, B., Boatwright, J.S., Honnay, O., Smets, E., Sprent, J., James, E.K. and Muasya, A.M. 2015. Symbiotic diversity, specificity and distribution of rhizobia in native legumes of the Core Cape Subregion (South Africa). FEMS Microbiol. Ecol. 91: 117.

Mehlich, M. 1984. Mehlich 3 soil test extractant: a modification of the Mehlich 2extractant. Comm.Soil Sci. Plant Anal. 15: 1409-1416.

Mosquera, A. and Mombiela, F. 1986. Comparison of three methods for determination of soil $\mathrm{Al}$ in an unbuffered salt-extract. Comm. Soil Sci. Plant Anal. 17(1): 30-35.

Murphy, J . and Riley, J.P. 1962. A modified single solution method for determination of phosphate in natural waters. Anal. Chem. Acta. 27: 31-36.

Mwenda, G.M., Karanjac, N.K., Boga, H., Kahindi, J.H.P., Muigai, A. and Odee, D. 2011. Abundance and diversity of legume nodulating rhizobia in soils of embu district, Kenya. Trop. Subtrop. Agroecosys. 13: 1-10.

National Institute of Cartography 2010. National Atlas of Physical Development of Cameroon. p.72.

Newton, W.E. 1998. Nitrogénases: fonction et évolution. Bull. Soc. Franç. Microbiol. 13: 238-241.

Philpotts, H. 1975. The effect of lime and rhizobium strain on the nodulation of Glycine wightii and Macroptilium atropurpureum on acid soils. Trop. Grassl. ymp. 9(1): 37-43.

Postgate, J.R. 1974. Evolution within nitrogenfixing systems. Symp. Soc. Gen. Microbiol. 24: 263-292.

Rees, D.C. and Howard, J.B. 2000.Nitrogenase: standing at the crossroads. Curr. Opin. Chem. Biol. 4: 559-566.

Sarr, P.S., Yamakawa, T., Fujimoto, S., Saeki, Y., Thao, H.T.B. and Myint, A.K. 2009. Phylogenetic diversity and symbiotic effectiveness of root-nodulating bacteria associated with cowpea in the south-West Area of Japan. Microbes Environ. 24(2): 105-112.

Slattery, J.F., Coventry, D.R. and Slattery, W.J. 2001. Rhizobial ecology as affected by the environment. Aust. J. Exp. Agric. 41: 289298.

Slattery, W.J., Conyers, M.K. and Aitken, R.L. 1999. Soil $\mathrm{pH}$, aluminum, manganese and lime requirement. pp. 103-128. In: Peverill, K.I., Sparrow, L.A., Reuter, D.J. (eds.). Soil analysis: an interpretation manual. CSIRO Publishing, Collingwood, Mebourne, Australia.

Somasegaran, P. and Hoben, H.J. 1985. Methodsin legumes-Rhizobium technology. NIFTAL project. University of Hawaii, Paia, Honolulu.

Vincent, J.M. 1970. A manual for the practical study of the root nodule bacteria. Blackwell Scientific Publications, Ltd., Oxford, UK. p. 164. 